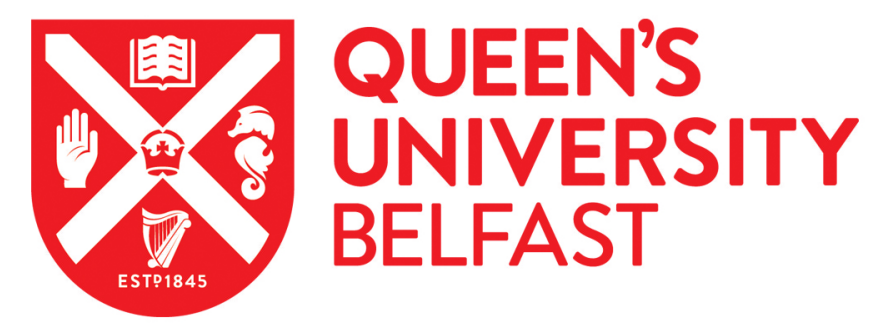

\title{
Parents as stakeholders: Language management in urban Galician homes
}

Nandi, A. (2018). Parents as stakeholders: Language management in urban Galician homes. Multilingua, 37(2), 201-223. https://doi.org/10.1515/multi-2017-0020

\author{
Published in: \\ Multilingua
}

Document Version:

Publisher's PDF, also known as Version of record

Queen's University Belfast - Research Portal:

Link to publication record in Queen's University Belfast Research Portal

\section{Publisher rights}

(c) 2018 Walter de Gruyter $\mathrm{GmbH}$.

This work is made available online in accordance with the publisher's policies. Please refer to any applicable terms of use of the publisher.

\section{General rights}

Copyright for the publications made accessible via the Queen's University Belfast Research Portal is retained by the author(s) and / or other copyright owners and it is a condition of accessing these publications that users recognise and abide by the legal requirements associated with these rights.

Take down policy

The Research Portal is Queen's institutional repository that provides access to Queen's research output. Every effort has been made to ensure that content in the Research Portal does not infringe any person's rights, or applicable UK laws. If you discover content in the Research Portal that you believe breaches copyright or violates any law, please contact openaccess@qub.ac.uk. 


\title{
Anik Nandi* \\ Parents as stakeholders: Language management in urban Galician homes
}

https://doi.org/10.1515/multi-2017-0020

\begin{abstract}
Macro-level policy makers, perceived as stakeholders of language management, employ a range of language policy strategies to legitimise hegemonic control over meso- (i.e. family) and micro- (i.e. individual) level language ideologies (Cassels-Johnson 2013). However, language policies of an individual are often difficult to detect because they are implicit, subtle, informal, and often hidden from the public eye, and therefore frequently overlooked by language policy researchers and policy makers. The primary focus of this study is to investigate how individual, as well as collective linguistic practices of Galician parents act as language governmentality (Foucault 1991) measures influencing their children's language learning. Drawing from multiple ethnographic research tools, including observations, in-depth fieldwork interviews and focus group discussions with parents, this paper demonstrates that in Galicia's language shift-induced shrinking Galician-speaker pool, pro-Galician parents can play an important role in the language revitalisation process. The goal is also to ascertain whether these parents' grassroots level interrogation of the dominant Castilian discourse takes the form of bottom-up language policies.
\end{abstract}

Keywords: family language policy, parental agency, language management, governmentality, Galician

\section{Introduction}

Language policy, as Spolsky (2009: 1) argues, “is all about choices”, and one of the major objectives of a language policy is "to account for the choices made by individual speakers on the basis of rule-governed patterns" that are generally approved by the members of a speech community. Additionally, inside the home domain, every family has its own norms for language use (Fogle 2013). Language policies, whether at macro-, meso- or micro-level, include three interrelated, albeit independent, factors: language ideologies, language management, and language practices (Spolsky 2004). Language ideologies, which are pivotal at

*Corresponding author: Anik Nandi, School of Arts, English and Languages, Queen's University Belfast, 7, University Square, Belfast, BT7 1NN, United Kingdom, E-mail: A.Nandi@qub.ac.uk 
any level of language policy, are manifested through linguistic practices. In this regard, in the family context, individual parents often mobilise their ideologies through their "language choices in interaction and hence socialize their children into this ideology" (Lanza 2007: 61). Language decisions or 'management', on the other hand, has been defined as conscious and explicit efforts made by actors who maintain or intend to exert control over the subjects in a specific context to modify their language behaviour (Spolsky 2009: 1-4). Since parents are the in-situ language planners inside the home, language management at the family level refers to the choices and attempts that parents make to maintain a language (King 2016).

In this paper, I focus on how individual as well as collective linguistic practices of Galician parents act as language 'governmentality' (Foucault 1980; Foucault 1991) measures, influencing their children's language learning. In addition, I address how these parents' grassroots interrogation of the dominant Castilian discourse takes the form of bottom-up language policies. Parents interviewed for this study include both traditional and new speaker (neofalantes) of Galician. A Galician neofalante has been defined as a person who is brought up speaking Castilian, but who at some stage in his/her life (often during youth or early adulthood) "becomes" a speaker of Galician and currently uses Galician to varying degrees in his/her everyday life (O’Rourke and Ramallo 2015).

This article commences with a brief outline of the sociolinguistic situation of Galicia, including its top-down language policies and their immediate impact on the urban milieu. This is followed by a theoretical overview of language management inside the home. The next section offers an account of the research methodology and finally provides a thematic analysis of the collected data.

\section{The sociolinguistic situation in Galicia: a brief outline}

Galician is a language variant of the western Ibero-Romance branch, spoken in Galicia, a bilingual (Castilian/Galician) Autonomous Community in the northwestern part of Spain. Galicia has four provinces, namely A Coruña, Ourense, Pontevedra and Lugo (see Figure 1). The following map of Galicia shows the geographical locations of these provinces, including Santiago de Compostela (henceforth Santiago), the capital of this Autonomous Community: 


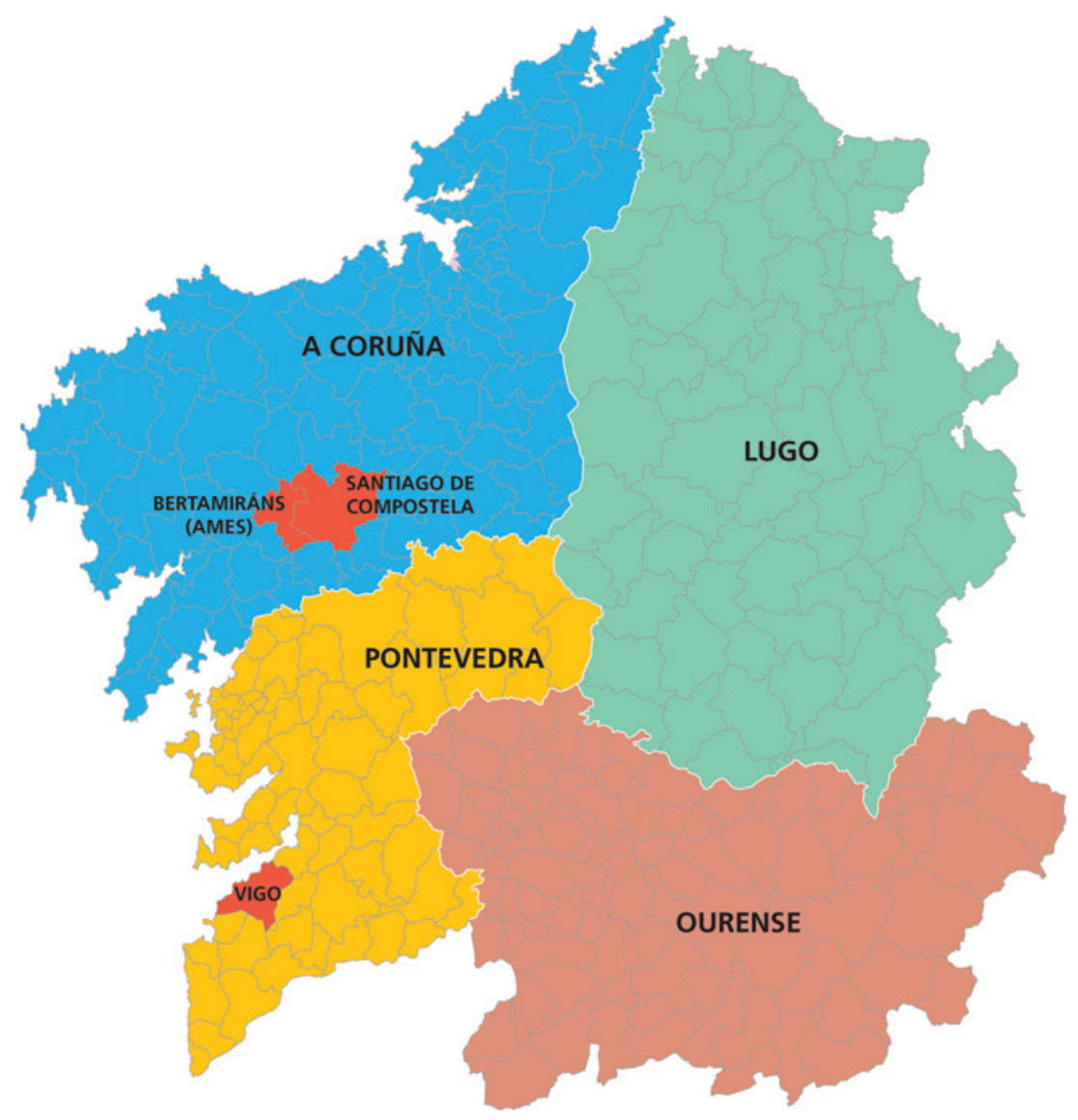

Figure 1: Provincial map of Galicia.

(Source: author's own elaboration of the provincial map of Galicia)

Galicia's present population is around three million people (Galician Institute of Statistics, henceforth IGE 2014). According to the last sociolinguistic survey, carried out in 2013 by IGE (published in 2014), of the total Galician population, 41\% reported to have Galician as their L1, which constitutes a drop of $22 \%$ over ten years. By contrast, $31 \%$ of the total population claimed to have Castilian as their L1, which indicates an increase of $2.1 \%$ since 2003; another $25 \%$ of the population stated that they were brought up speaking both languages, indicating an increase of $54 \%$ since 2003. As the above data demonstrate, there is a constant decrease in the number of predominant Galician speakers (see also Monteagudo et al. 2017). The vulnerability of Galician is still largely attributable to an aging and rural-based population (ibid). It 
is also important to note that these macro-level census data, although offering a general overview of the situation, are often unable to grasp the grassroots-level discourses about language maintenance and shift (Urla 2012). Therefore, for a more comprehensive understanding of the issue, bottom-up ethnographic research is required.

In the Galician sociolinguistic situation, "prestige" is afforded to the dominant language - Castilian (Monteagudo 2012). Until the first half of the twentieth century, most of the Galician population lived in rural areas where Galician was the only language of communication; gradual emigration to urban areas since the midtwentieth century has destabilised the rural demographic base of Galician. As Castilian was already the predominant language in the cities, the process of language shift towards Castilian in urban territories seemed a fait accompli (Ramallo 2012). Later, the top-down language policy and planning (henceforth LPP) during the Franco regime (1939-1975) made the use of Castilian compulsory as the sole language for administration, education, and media in Galicia. During this period, the use of Galician was mostly restricted to the home domain and to informal conversations which further reinforced the diglossic situation (Del Valle 2000). After Franco's death in 1975, democracy returned and Galicia was recognised as one of the Autonomous Communities of Spain. Later, in 1981, the Galician Statute of Autonomy accepted Galician as Galicia's lingua propia (own language). In 1983, top-down language policy models were put in place in line with the Law of Linguistic Normalisation of Galician (Lei de Normalización Lingüística - LNL) to boost the use of this minority language in the public domain; it also made the knowledge of Galician a sine qua non for all public-sector employees.

Although the legal stipulation was that, apart from Galician language and literature, at least two to four subjects should be taught in Galician, various schools (particularly urban schools) were in fact not fulfilling this obligation (Silva-Valdivia 2010). However, the policy stakeholders of the conservative centralist Government of Partido Popular de Galicia (People's Party of Galicia, $\mathrm{PPdeG}^{1}$ ), which had been in power almost uninterruptedly during the initial years of language policy in Galicia (1982-2004), took very little interest in implementing the policy initiatives on the ground. This is because they were more interested in not upsetting certain Castilian-speaking urban middle-class people in the Galician society (Alvarez-Cáccamo 2011). Thus, during the first two decades, the government was mainly concerned about maintaining the status

1 Partido Popular de Galicia (PPdeG): Partido Popular (PP) is a conservative centre-right wing Spanish political party founded in 1989. Partido Popular de Galicia (PPdeG), on the other hand, is an affiliated branch of PP which has been in power in Galicia almost uninterruptedly between 1990-2005 and then again since March 2009-present. 
quo of equal co-existence of Castilian and Galician, which in turn, favoured a laissez-faire model of LPP with a minimum implementation at the grassroots level (Lorenzo-Suárez 2005).

In 2010, PPdeG introduced changes to the existing language education policy through a new decree entitled $O$ Decreto de Plurilingüismo (The Decree of Plurilingualism, henceforth DDP). Although this new policy claims to ensure the use of Galician in pre-university education curricula along with Castilian, it allows the medium of instruction to be the children's home language. There is a discordant and indeed paradoxical element in this policy; since Castilian has been, and still is, the most widely used language in urban/semi-urban domains, most children tend to be brought up speaking Castilian by Castilian-speaking parents. Therefore, with the implementation of this decree, Castilian automatically became the medium of instruction in the urban pre-schools, which further restricted the domains of use of Galician among these pupils. Ever since this topdown LPP was put into practice, language shift to Castilian in urban contexts has received a momentum which is evident from recent macro-level demo-sociolinguistic data of IGE in December 2014, as the number of adolescents who never spoke Galician has increased by $17 \%$ in the last five years.

As soon as the abovementioned data were made public, the decree came under critical inspection. Responding to various critiques, government stakeholders, including the President of the Xunta de Galicia (Government of Galicia) and the former Education Minister of Galicia put forward the discourses of "responsibility of family" and "individual liberty of language choice in a bilingual society" as justifications for the incessant language shift to Castilian (Hermida 2014; Álvarez 2014). The above circumstances raised an issue about whether the intergenerational transmission of Galician was a result of Galician parents' language management decisions, or whether there were larger sociopolitical, economic, linguistic, cultural, and other structural variables at play in determining the future of Galician. Notably, parental language policies within the home are hard to detect as they are subtle, informal, and often hidden from the public eye (King et al. 2008). Therefore, it is important to investigate parental language management decisions within the family domain.

\section{Parental language management: a critical perspective}

Top-down language policy is perceived as governmental measures, designed to influence "people's linguistic lives" (Shohamy 2006: 185). In this regard, the 
state, which is initially a representative of the public sphere, is also responsible for creating and implementing the top-down LPP, instilling it into the public domain through various ideological state apparatuses (Althusser 1971), such as the school, religious institutions and mass media. Although these apparatuses are not necessarily under the state's control, they can often be used to perpetuate top-down ideologies. Therefore, it can be argued that family members are "always already" (Derrida 1976: 159) ideologically influenced by the state. In other words, the separation of the family or individual domain from the larger society is impossible (Foucault 1980). Whereas macro-level language policies are designed to regulate and govern social structures, home language choices and practices are essentially influenced by the individual family's perception of the macro social structures (Nandi 2016). Consequently, language policies of the individual and/or the family involve the internal dimensions of ideological positions of every family member and the external force of the top-down policy (Curdt-Christiansen 2009).

One of the most significant aspects of FLP, language management, refers to the specific interventions implemented to change or influence individuals' language behaviours (Shohamy 2006: 53). A family’s language management is very much determined by home language environments, family members' knowledge about societal bilingualism, different forms of family capitals, and parental input among others. Home language environments refer to several literacy-related resources, including books, music, rhymes and e-resources among others. Several studies in FLP (see Curdt-Christiansen 2013; CurdtChristiansen 2016; Smith-Christmas 2016) have confirmed that when a home environment is rich in literacy materials and when the family members are supportive of home language maintenance, children's literacy development will be improved. Relatedly, a family's resources include all forms of material and cultural, social or symbolic capital that can be converted into educational accomplishment of children. Another significant element of language management is parental involvement, comprising a range of formal as well as informal literacy activities, such as joint book reading, explicit teaching, helping during homework or, in some cases, seeking external professional help from private tutors and discussing children's school activities and experiences with them.

Curdt-Christiansen (2014: 38) argues that the distinction between language management and practice within the home domain "is somewhat blurred as parents may control or intervene in their children's discourse behaviour in their everyday talk". Such intervention strategy evokes discourses of 'language governmentality' and 'biopower' (Foucault 1991; Foucault 2007). Language governmentality is an extension of Foucault's (1978) notion of 
'governmentality'. Foucauldian notions have been used extensively by critical language policy researchers to examine top-down LPP regimes (see Flores 2013; Cassels-Johnson 2013; Martin-Rojo 2017). These two concepts are also particularly relevant for understanding of the home language planning decisions.

Foucault (1978) argues that human activity is rule-governed, in part through a range of discursive practices stemming from institutions, social relationships and strategies of communication which make certain ways of talking, being and acting 'normal'. He (1991: 102) defines 'governmentality' as:

The ensemble formed by institutions, procedures, analyses and reflections, calculations, and tactics that allow the exercise of this very specific, albeit complex, power that has the population as its target, political economy as its major form of knowledge, and apparatuses of security as its essential technical instrument.

In other words, 'governance' can be described as an attempt to shape human conduct by calculated means through various disciplinary apparatuses which will mould the civilians into the desired ideal (Flores 2013). Exercise of power at different levels of civil society play a significant role in this process. According to Foucault, 'power' is an asymmetrical network of relations which does not exclusively reside with the state or within their policies, instead power is everywhere, like a web. He (1980: 39) further notes that power "reaches into the very grain of individuals, touches their bodies and inserts itself into their actions and attitudes, their discourses, learning processes and everyday lives." Foucault therefore interprets power in terms of "strategies" that are produced through the nexus of the power relations which is ubiquitous wherever people interact. Even though he never offers any clear explanation of the origin of power, he certainly recognises that it is much easier to detect who does not have power. Along somewhat similar lines, Martin-Rojo (2017: 77) underscores that power is not only experienced, it is also practised in a variety of social encounters in which "participants have to define who has access to the management of power resources and technologies."

In this sense, language governmentality can be understood in relation to how decisions about language(s) are made across a diverse range of establishments, including family, school and mass media, through a diverse range of tools, such as books, regulations and interventions to control language practices, ideological belief systems, and actions of individuals. Therefore, parental language management or planning decisions can also be considered as a form of language governmentality (Nandi and Devasundaram 2017).

Within the home domain, adult family members often implement a range of monitoring techniques to attain a desired linguistic outcome from the children. 
This situation evokes the discourses of 'bio-politics' or 'biopower', which has been defined as "the set of mechanisms through which the basic biological features of the human species became the object of a political strategy, of a general strategy of power...” (Foucault 2007: 1). For Foucault, governmentality subsumes biopower. Therefore, bio-politics can be considered as a technology of power that evolves on the basis of disciplinary power. While discipline is about controlling individual bodies, biopolitics is about controlling entire populations (Foucault 1991). In the context of family, biopower is reflected through parental agency and control mechanisms used by them as progenitors. Thus, they act as primary stakeholders of FLP and assume the role of custodians over their children's language practice, perceiving this "ownership” as a putative parental right. How this is exercised by contemporary urban/semi-urban Galician parents will be discussed later in this article. The following section offers a methodological outline of this research.

\section{Locating the site}

Ethnographic research tools have been used for data collection. Ethnography is described as a "way of seeing" that is situated and systematic and a "way of looking" that is based on in situ, long-term and first-hand fieldwork (Canagarajah 2005). Thus, primary data for this study were gathered from (I) field notes and observations from research sites (see figure 1), from (II) in depth semi-structured interviews with individual parents and from (III) two focus group discussions. In policy research, in-depth semi-structured interviews are considered as a highly effective tool to understand how home language planning and classroom pedagogy interact with top-down policies. Focus groups, on the other hand, can offer deeper insights on specific issues, such as explanations about policy choices, alternatives and grassroots level perceptions of policy matters. As a method, it can provide a context for participants from similar backgrounds to share their opinions dynamically and co-construct meaning as a collective in due course (Markova et al. 2007). In this study, focus groups were used to consolidate the data collected from in-depth semi-structured interviews. Therefore, they were more narrowly centred on family language policies of pro-Galician parents, especially on those who maintain an activist profile.

This research centres on pro-Galician parents who have gone through the Galician education system after 1980 and thus have experienced the postFranco language policies. In other words, they can be considered as the outcomes of the language revitalisation strategies put in place in Galicia following 
Spain's transition to democracy. The participants of this study are educated middle-class parents from an urban/semi-urban background between 35 and 50 years of age. The higher age range of the interviewees ensures the presence of parents who have experienced the education system's transition from the Franco regime to Galician Autonomy. Most participants are public sector employees from three urban/semi-urban areas, including Santiago, Bertamiráns and Vigo (see figure 1), who often use Galician at work according to the legal stipulation. Therefore, I was interested in investigating family language management of this educated middle-class sector of the population. It is also necessary to note here that this article presents the results of a larger body of doctoral research, which draws from eighteen in-depth semi-structured interviews and two focus group discussions with couples from five different urban/semi-urban regions of Galicia. This paper uses data from three individual interviews from Bertamiráns and two focus groups, conducted in Santiago and Vigo with four families each.

To gain access to the research participants in Santiago, Bertamiráns and Vigo, I relied on multiple gatekeepers and key informants due to my previous contact with the community. While the focus groups were conducted in Galician, individual interviews were conducted in either Castilian or Galician, depending on the participant's preference. The schools at Bertamiráns and Vigo are public schools, whereas parents in Santiago send their children to two cooperative-funded Galician-medium immersion schools: Raiola (Ray of Sunshine) and Escola Semente (School of seeds). During fieldwork, it was noted that while Raiola had been offering Galician as a medium of instruction for more than forty years, Escola Semente started more recently, in 2011, as an exigent response to the state's extant language policy 'The Decree of Plurilingualism'. Escola Semente, akin to Raiola, is a language immersion school, initially funded by a group of pro-Galician parents who sought to educate their children in Galician. At present, the Parents' Association of Semente has more than 90 members who actively support the endeavour to defy the official language policy from the grassroots. Three of this study's focus-group respondents from the Parental Association of Semente school also belong to a pro-Galician parents' collective, Tribo (the tribe).

Tribo started as a WhatsApp messenger group in July-August 2013. It now includes more than 40 families who meet very often to enable their children to socialise and converse in Galician (Bal and Rodríguez 2014). The main intention of Tribo, as described by its members in focus-group discussions and during observations, is to prevent language shift during their children's early years. Parents interested in joining the collective generally contact the 
group members though WhatsApp, a technological interface that allows Tribo members to collectively exchange messages. The members of this group also communicate informally amongst themselves, meeting in different places in Santiago to organise or participate in various extracurricular or cultural activities that involve their children's interaction in Galician. With the help of my key participants, I got access to observe closely these Tribo members and some of their actions. How these activist parents attempt to extend their pro-Galician FLP to the education system through cooperative-funded Galician medium schools will be discussed later in this paper.

The following chart (see Table 1) gives an overview of the parents interviewed, including their age groups, speaker profile, predominant home language, geographical locations, and occupations. Fictitious names have been used to protect the real identity of the respondents.

Table 1: Profiles of participating families

\begin{tabular}{|c|c|c|c|c|}
\hline No. & $\begin{array}{l}\text { Parents' details and } \\
\text { their predominant home } \\
\text { language }\end{array}$ & Age & $\begin{array}{l}\text { Details about children and } \\
\text { school }\end{array}$ & Occupations \\
\hline \multicolumn{5}{|c|}{ Individual interviews } \\
\hline 1 & $\begin{array}{l}\text { Javier (neofalante) } \\
\text { Julia (neofalante) } \\
\text { Dominant language: } \\
\text { Castilian } \\
\text { Location: Bertamiráns }\end{array}$ & $\begin{array}{l}39 \\
36\end{array}$ & $\begin{array}{l}\text { Their two children study in the } \\
\text { public primary school at } \\
\text { Bertamiráns }\end{array}$ & $\begin{array}{l}\text { Veterinary } \\
\text { (Government employee) } \\
\text { Veterinary } \\
\text { (Government employee) }\end{array}$ \\
\hline 2 & $\begin{array}{l}\text { Ana (neofalante) } \\
\text { Dominant language: } \\
\text { Castilian } \\
\text { Location: Bertamiráns }\end{array}$ & 42 & $\begin{array}{l}\text { Her two children study in the } \\
\text { Public primary school at } \\
\text { Bertamiráns }\end{array}$ & Psychologist \\
\hline \multicolumn{5}{|c|}{ Focus group participants } \\
\hline 3 & $\begin{array}{l}\text { Mercedes (neofalante) } \\
\text { Salvador (traditional } \\
\text { speaker) } \\
\text { Dominant language: } \\
\text { Galician } \\
\text { Location: Santiago }\end{array}$ & $\begin{array}{l}39 \\
40\end{array}$ & $\begin{array}{l}\text { Their daughter studies in } \\
\text { Semente school at Santiago }\end{array}$ & $\begin{array}{l}\text { Small to medium } \\
\text { enterprises (SME): owns } \\
\text { a souvenir shop in the } \\
\text { old town of Santiago. }\end{array}$ \\
\hline 4 & $\begin{array}{l}\text { Bea (traditional speaker) } \\
\text { Claudio (neofalante) } \\
\text { Dominant language: } \\
\text { Galician } \\
\text { Location: Santiago }\end{array}$ & $\begin{array}{l}35 \\
39\end{array}$ & $\begin{array}{l}\text { Their daughter studies in } \\
\text { Raiola school at Santiago }\end{array}$ & $\begin{array}{l}\text { Nurse } \\
\text { Government employee } \\
\text { (not present) }\end{array}$ \\
\hline
\end{tabular}


Table 1: (continued)

\begin{tabular}{|c|c|c|c|c|}
\hline No. & $\begin{array}{l}\text { Parents' details and } \\
\text { their predominant home } \\
\text { language }\end{array}$ & Age & $\begin{array}{l}\text { Details about children and } \\
\text { school }\end{array}$ & Occupations \\
\hline 5 & $\begin{array}{l}\text { Lara (neofalante) } \\
\text { Adam (traditional } \\
\text { speaker) } \\
\text { Dominant language: } \\
\text { Galician } \\
\text { Location: Santiago }\end{array}$ & $\begin{array}{l}40 \\
47\end{array}$ & $\begin{array}{l}\text { Their son studies in Semente } \\
\text { school at Santiago }\end{array}$ & $\begin{array}{l}\text { Teacher (Government } \\
\text { employee) } \\
\text { Worked as salesman } \\
\text { but now unemployed }\end{array}$ \\
\hline 6 & $\begin{array}{l}\text { Elena (neofalante) } \\
\text { Virgilio (neofalante) } \\
\text { Dominant language: } \\
\text { Galician } \\
\text { Location: Santiago }\end{array}$ & $\begin{array}{l}38 \\
41\end{array}$ & $\begin{array}{l}\text { Their son studies in Semente } \\
\text { school at Santiago }\end{array}$ & $\begin{array}{l}\text { Journalist at Xunta } \\
\text { (Government employee) } \\
\text { Telecommunications } \\
\text { engineer }\end{array}$ \\
\hline 7 & $\begin{array}{l}\text { Xoan (traditional } \\
\text { speaker) } \\
\text { Maite (traditional } \\
\text { speaker) } \\
\text { Dominant language: } \\
\text { Galician } \\
\text { Location: Vigo }\end{array}$ & $\begin{array}{l}45 \\
46\end{array}$ & $\begin{array}{l}\text { Their two sons are studying at } \\
\text { a public primary school in } \\
\text { Vigo }\end{array}$ & $\begin{array}{l}\text { Administrator } \\
\text { (Government employee) } \\
\text { Administrator } \\
\text { (Government employee) }\end{array}$ \\
\hline 8 & $\begin{array}{l}\text { Inma (neofalante) } \\
\text { Cesar (neofalante) } \\
\text { Dominant language: } \\
\text { Galician } \\
\text { Location: Vigo }\end{array}$ & $\begin{array}{l}42 \\
45\end{array}$ & $\begin{array}{l}\text { Their two children studying in } \\
\text { the public primary school at } \\
\text { Vigo. }\end{array}$ & $\begin{array}{l}\text { Translator at Xunta } \\
\text { (Government employee) } \\
\text { Administrator } \\
\text { (Government employee) }\end{array}$ \\
\hline 9 & $\begin{array}{l}\text { Paloma (neofalante) } \\
\text { Dominant language: } \\
\text { Galician } \\
\text { Location: Vigo }\end{array}$ & 34 & $\begin{array}{l}\text { Her son attends a public } \\
\text { primary school at Vigo. }\end{array}$ & Unemployed \\
\hline 10 & $\begin{array}{l}\text { Dario (neofalante) } \\
\text { Sabela (traditional } \\
\text { speaker) } \\
\text { Dominant language: } \\
\text { Galician } \\
\text { Location: Vigo }\end{array}$ & $\begin{array}{l}40 \\
38\end{array}$ & $\begin{array}{l}\text { Their daughter studies in the } \\
\text { public primary school at Vigo. }\end{array}$ & $\begin{array}{l}\text { Stage director } \\
\text { Teacher } \\
\text { (Government employee) }\end{array}$ \\
\hline
\end{tabular}

Thematic analysis was decided on as the medium of data interpretation. In ethnographic inquiry, this type of analysis can offer useful explanations of the multiple personal-experience narratives as they offer first-person insights into individual's linguistic ideologies, management and practices (McCarty 
2015). Themes can be defined as patterns across data that are relevant to the description of a phenomenon and are associated with a specific research question (Braun and Clarke 2006). As such, once the transcription was completed, the dataset was read repeatedly in keeping with the recordings to ensure the accuracy of the transcription. Field notes were also studied carefully at this stage to support and expand the interview data. This led to the production of initial codes from the data. Once the initial coding was done, the codes were revisited to avoid redundancies. Modified codes that were relevant to language management decisions are merged into different categories. These categories were then grouped under four major themes: individual parents' agency in home language management, developing a favourable literacy atmosphere for Galician, prestige planning within family, and collective language governmentality in creation of bottom-up LPP. These themes will be discussed in the following section.

\section{Language management in urban Galician homes}

This section offers an overview of language management strategies from proGalician parents and demonstrates how their individual language management and practices, when galvanised into collective mobilisations, can impact language behaviour at the grassroots.

\subsection{Individual parents' agency in home language management}

Reported language practices of individual parents seem to confirm that each of them exercises his/her individual language practices at home. In this study, all the parents unanimously emphasised the role of family in intergenerational transmission. In the context of this study, most Galician-speaking parents including neofalantes, especially those who participate actively in the language revitalisation discourse, confirmed that they had no reservations in choosing Galician as their home language, while couples who spoke both Castilian and Galician or predominantly Castilian were in continuous negotiation about their language choice inside the home. For instance, Ana, a mother from Bertamiráns who did not have Galician as her L1 but had learnt the language in school and was now a proficient user of Galician, stated that she intended to incorporate it into her day-to-day life. However, her family speaks predominantly Castilian at home: 
Co paso de tempo, si que é verdade With time, yes, it is true that I tried on que eu pola miña conta pois tratei de my own to learn and apply Galician in aprender e de tratar de aplicar o my day to daylife, not only to know it galego a vida cotidián, no solamente academically. But, well, my main sabelo académicamente. Pero bueno, language is Castilian. I try to speak a miña lingua fundamental si que é Galician every moment though. verdade que é o castelán. Trato de (Emphasis added) falar cada minuto en galego. [In Galician]

[Recorded interview, 27.11.13]

Even though her knowledge of Galician is mostly acquired from books, Ana clearly states that she attempts to exceed her academic knowledge of Galician and expand its horizons by incorporating it practically in her daily life. She further claims to speak with her daughter in Galician for at least an hour every day. Ana adds that if they start speaking in Galician during dinner, her partner and their eldest son normally participate in the conversation, switching from Castilian to Galician:

(...) hai pouco a miña nena que fala castelán habitualmente dixo: "Por que non buscamos un momento para falar un ratiño en galego todos en casa?” E pareceunos moi ben. E buscamos a hora da cea que e cando estamos todos xuntos. [In Galician]
(...) my daughter, who speaks mostly Castilian, said: Why don't we find a moment when all of us will speak in Galician? We liked the proposal, and we selected dinner time for this exercise, since that's the time when we all are together. (Emphasis added) [Recorded interview, 27.11.13]

Significantly, Ana's conscious personal decision on expanding the domain of Galician in her everyday life is crucially instantiated by its deployment as language management in the family context.

Javier and Julia, a couple from Bertamiráns, although they use mostly Galician at work, converse in Castilian at home. Regarding the daily language use of their children, the parents admit that although the children sometimes use certain words in Galician, they speak mostly Castilian. Their daughter studies in a primary school at Bertamiráns, with whom Javier claims to speak Galician: 
(...) coa miña filla, teño dous nenos (...) including my daughter, I have two pequenos, a maior, me comprometín small children, with the elder, I decided a falar en galego. Dixen, nada, pois, to speak in Galician. I said between us, entre nós imos falar en galego (...) we will speak in Galician (...) (Emphasis [In Galician] added)

[Recorded interview, 21.11.13]

Firm lexical choices such as Javier's "I decided to speak in Galician” and "between us we will speak in Galician" underscore that he assumes the role of a stakeholder over his daughter's habitual linguistic practices. This claimed linguistic practice can be labelled as an evidence of biopower exercised through parental agency where Javier considers this 'authority' as his putative parental right. However, in reality, as Julia notes, Javier often forgets to speak in Galician:

Se le olvida casi siempre (risas). He forgets quite often (laughs). He tries to Él lo intenta, pero se le olvida. [speak in Galician with their children], but he often forgets.

[In Castilian] [Recorded interview, 13.05.14]

During the interview, Julia also alludes to their very often failed attempts to speak more Galician at home. She relates this to the fact that both she and her husband have Castilian as their first language. Therefore, they attempt to compensate this imbalance through various pro-Galician literacy practices, such as introducing Galician through songs and bedtime stories:

Lo intentamos en algún momento, pero no lo conseguimos, lo que tenemos en casa es lecturas, muchísimas lecturas en gallego, y la música infantil es prácticamente toda en gallego... Cantamos en gallego, leemos mucho en gallego, pero conversación en gallego tenemos muy poca. Y tenemos que mejorarlo.

[In Castilian]
We have tried at some point but we couldn't manage it [speaking Galician at home], what we have at home are books, lots of books in Galician, and almost all children's music is in Galician. We sing in Galician, we read a lot in Galician, however, we have very little conversation in Galician. We have to make this better. (Emphasis added)

[Recorded interview, 13.05.14]

Reported language practices in the above case demonstrate how the Castiliandominated exterior penetrates the interior home space. Javier and Julia's articulations and attestations of fidelity to Galician, and their hope for its furtherance 
in their home space seem to be contradicted by continuous interruptions. In this regard, their claimed commitment to Galician is offset by the couple's and their children's intermittent lapses into Castilian. This inconsistency between affirmation of Galician and compliance or capitulation to Castilian denotes the potency of Castilian's practical and ideological dominance in the urban Galician milieu. This situation is primarily linked to the historical development of Castilian in this region, which is further reinforced by top-down pro-Castilian governmentality through laissez-faire LPP models for the past three decades. The above excerpts nonetheless underscore the parental biopower exerted by these proGalician parents, such as Javier and Ana, to consciously interrogate and combat the monolingual monopoly of Castilian from the ground, mostly within the family domain, and increasingly, as we shall see, beyond its precincts.

\subsection{Developing a favourable literacy atmosphere for Galician}

Several pro-Galician parents from the focus group in Santiago highlighted the insufficiency and inadequacy of the learning materials in Galician available to children. These parents further voiced their relentless efforts to locate and access such literacy related resources:

Virgilio: [O que pasa é que] é unha desventaxa numérica.

Elena: Claro.

Bea: [Efectivamente]. Si.

Lara: E que é o dobre (...)

Elena: A tele pesa moitísimo. E a tele si que maioritariamente o produto que tes é en castelán.

Mercedes: É que non hai.

Virgilio: Que estar facendo como pais [un labor]

Mercedes: [Claro.]

Virgilio: Que ás veces o facemos polo que estou escoitando [todos].

Salvador: [Xa.]
Virgilio: What happens is that there is a numerical disadvantage.

Elena: Of course.

Bea: Indeed.

Lara: The thing is that it's double (in Castilian)

Elena: Television influences a lot, too. And in the television, most of the programmes are in Castilian.

Mercedes: The thing is that we don't have [sufficient TV programmes in Galician].

Virgilio: That we have to do lot of effort as

Mercedes: Of course.

Virgilio: That we often do as I am hearing from other parents.

Salvador: Yes. 
Adam: [Nós vamos, nós tódalas] semanas ou casi tódalas semanas vamos á biblioteca a buscar [pelis] Lara: Si.

[In Galician]
Adam: We go to the library almost every week to search for films.

Lara: Yes.

[Recorded focus group discussion, 14.12.14]

The above situation not only underscores parental concerns about intergenerational transmission of Galician, but also the practical challenges they encounter in everyday contexts. Pro-Galician parents' language management to develop a favourable literacy atmosphere in the minority language inside the home domain is also evident from the above extract.

\subsection{Prestige planning at home}

Some pro-Galician parents also show awareness of this cultural as well as ideological dominance of Castilian and are involved in a bottom-up discourse that melds their individual efforts with broader collective mobilisations. Since Castilian is the language of children's socialisation in the Galician urban terrain, these parents often emphasise the 'prestige planning' (Kaplan and Baldauf 1997) of Galician in the family domain. Prestige in this context is directly related to identity and pride that motivates the family members to use the minority language. Aspects of prestige planning are evident from the following comment of Dario, a discussant from Vigo, who underscores the parental role in developing prestige for the minority language at home, so that his children will not be ashamed of speaking Galician:

(...) Eu creo que o papel das familias, (...) I believe that the role of families, or ou polo menos o que eu sinto que at least what I feel that I have to carry teño que realizar co neno e coa nena, out with my children, is giving pride to é de dar orgullo ós nenos de ser quen the children of what they are, not only son, non so lingüisticamente, senón que se sintan dignos, que se sintan valentes, que teñen que ser independentes e teño a esperanza que si están reforzados desta maneira poderán defender o galego que se fala na casa (...) [In Galician] linguistically, but they should feel dignified, they should feel courageous and brave and they should feel that they have to be independent and I have the hope that if they are educated like this they can defend Galician as we speak at home (...) [Recorded focus group discussion, 20.12.14] 
To a large extent, Dario's language management strategy indicates the desire to enrich the symbolic capital of Galician inside the home, by instilling a sense of pride and self-identification in the use of the minority language. This active proliferation of Galician at home, as Dario expects, will help his children to enunciate and enact their Galician identity without 'fear' or 'shame', in the Castilian-dominated exterior.

Analogous to Dario, Elena, a mother from Santiago whose eldest son is studying in a public primary school, explains to him in the following anecdote that he should not feel alienated for speaking Galician:

O outro día, pois por exemplo, comentábanos "ás veces estou incómodo e prefiro pasarme ó castelán, e non sei que facer”, non? Entón nós tamén lle dicimos, "pois mira, nós tamén pasamos por esas. Pero igual que ti non renuncias a outras da túa personalidade ti es galego falante e non tes por que renunciar a ela no patio. Os teus amigos vante querer igual, i os que non te queren, non te queren por iso, non?” Quero dicir, si que llo racionalizamos dalgunha maneira, non? Non simplemente educámolo en galego e pra diante, senón que dalgunha maneira sabemos que se vai enfrontar con iso.

[In Galician]
The other day, for instance, he was telling us "sometimes I am uncomfortable and I prefer to change to Castilian and I don't know what to do". Then we told him, "look we also went through this. But, it [Galician] is part of your identity, which you don't renounce. You are a Galician speaker and there is no reason why you should abandon it when you are in the playground. Your friends will respect you as will others who don't like you for this". I would like to say, yes, we do try to rationalise this [situation] in a way (...) not simply lecture them and go ahead. If we don't, we know that he will get confrontational about this. [Recorded focus group discussion, 14.12.14]

Elena's comment further underlines the parental role in prestige planning of a minority language in the home domain. Above-mentioned experiences reveal how the interior home space of pro-Galician parents transforms into a constantly fluctuating field of agonistic negotiation of power relations with multiple determinants from the external sphere, such as the influence of their children's peers and the ideological impact of Castilian-speaking outside. Thus, these proGalician parents are not only preparing their children to face the hegemony of Castilian in the larger society, but also providing them with the necessary psychological strength and linguistic skills to contest the dominant discourse bottom-up. Their sense of responsibility, linguistic commitment and claimed 
practices towards Galician further underscore how these parents exercise their language governmentality measures and become implementers of language policy inside family domain.

\subsection{Collective language governmentality in creation of bottom- up LPP}

Bea, another mother from Santiago, states that, as parents, they are conscious about the socio-lingual inequality existent in the Galician society. Therefore, to impede language shift during the initial years of their children, they formed a pro-Galician parents WhatsApp group entitled Tribo, comprising a pro-Galician collective that wants their children to be educated and socialised in Galician:

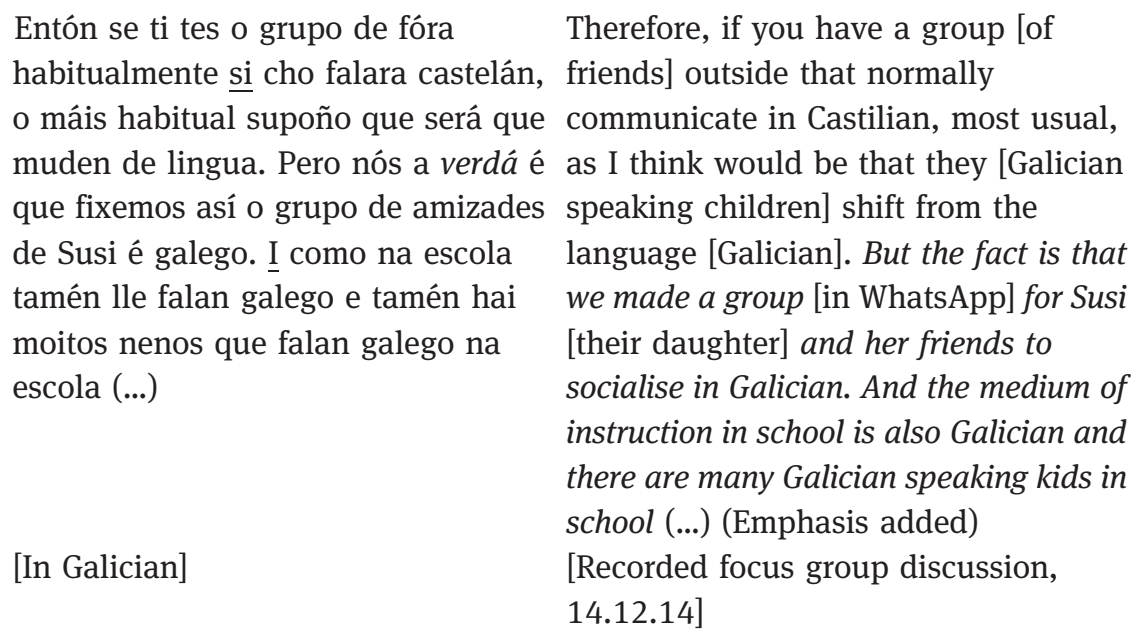

The above strategy can be considered as one form of bottom-up resistance from pro-Galician parents contesting the conventionalisation of Castilian. It further points to the parental language governmentality through selecting peers for their children that, as discussed before, can be considered as an aspect of parental language management. This scenario further evokes the discourses of biopower, where Bea and like-minded parents as progenitors take up the role of LPP stakeholders and attempt to create communication space and conditions for their children to use Galician.

Notably, parental language governmentality and exercise of biopower may sometimes adopt a major social role in minority language revitalisation contexts. In Galicia, for instance, as a reaction to the present top-down LPP, a collective of 
pro-Galician parents formed co-operatives to fund Galician medium immersion schools. These activist parents took this attempt with an intention to extend their pro-Galician FLP to the education system, as public schools were becoming a space for de-Galicianisation during the early ages. One of these schools is Escola Semente. Established in 2011, it is a language immersion school, initially funded by a group of pro-Galician activists who sought to reverse the language shift of Galician during children's early years.

During fieldwork, several visits have been made to Escola Semente. On 25.11.2014, my field note observation recorded the following:

Upon entering the school, I noticed that the school has two classrooms packed with children's learning materials in Galician, including posters, lyrics of traditional Galician songs, indoor games, storybooks, audio and video resources. One of the members from the parental association of Semente school explained that the parents can retain these literacy resources for a brief period and use them to develop an effective home literacy environment in Galician...

This demonstrates how Galician is being promoted at Escola Semente and how this institution is addressing the grassroots-level void in the form of the state's failure to supply adequate and accessible learning materials in Galician. Observational field notes from 10.12.2014 further reveal that

...after school hours, the school space is often used to host various language-learning extracurricular activities related to Galician with the children, including traditional music, dance and popular festivals such as Magosto, a festival of pagan origin celebrated in the commencement of autumn in Galicia. Notably, children from other pre-primary and primary schools can also participate in these group activities by paying the small course fee. Therefore, several group members of Tribo bring their children to participate in these events.

Such initiatives also dissolve distinctions between like-minded pro-Galician parents and open up alternative paths for their children to compare notes, interact and reinforce their verbal and written skills in Galician. In a Castiliandominated Galician urban landscape, the activities organised by Tribo can be interpreted as language governmentality measures to contest the conventionalisation of Castilian bottom-up coordinated by pro-Galician parents.

\section{Conclusion}

Breaking the binary of interior/exterior domains in the above-described scenarios involving pro-Galician parents demonstrates the inherent flexibility in the 
deliberation between Castilian and Galician. In essence, the sites for intersection and imbrication of the two linguistic discourses are subject to continuous negotiations, variations and mutations. Multiple endogenous and exogenous factors also play a role influencing the connection between the interior and exterior realms that impact the pro-Galician parents and their families' lived linguistic experiences. These factors include the media, education curriculum, peer-influence, tacit social customs and language practices that are associated with governmentality and bio-power. The last two, as this article demonstrates, can emerge not only from the state but also from parental control over children. These intertwined factors represent the network of power relations, from the micro-level of parental jurisdiction to the custodians of political power at the executive policy-making levels of the state (again from regional to federal levels and the layers in-between). Ultimately, state-imposed top-down language policies are designed to address and regulate social structures at all possible levels. Home language choices, managements and practices are therefore unavoidably biased by the individual family's perception of these dominant macro-political policies and their reverberations in wider social structures.

Due to Galician's presence in the education system since the 1980s, a generation of pro-Galician parents have emerged who do not have Galician as their home language, but who are driven by a strong ideological bond with Galicia. These parents have started widening the symbolic space for Galician. In a community, such as Galicia, where the existence of orthodox speakers shrinks perceptibly due to language shift, these pro-Galician parents, by creating alternative bottom-up language policies, can play an important role in the language revitalisation process from the ground. However, it remains to be ascertained whether these parents can effectively restore the process of intergenerational transmission of Galician in the home domain and within the community and, in turn, create new generations of speakers. This is because Castilian still maintains a greater degree of symbolic power in the urban Galician society, creating fluctuations, vacillations and inconsistencies in desired language practice in Galician-speaking homes. It is also important to note that symbolic capital, evident in the privileging of Castilian as the language of communication, is to some degree offset by pro-Galician activist parents at home and through their cooperative contestation (e.g., Raiola and Escola Semente) from the grassroots level. These language management endeavours could be interpreted as counterhegemonic strategies to destabilise the normalisation and legitimisation of the dominant discourse.

Reported linguistic practices of these parents also reveal that individual agency in language policy, like all other domains of language policy, includes aspects of ideology, management, and practice. Language policies of the 
individual, as this study reveals, entail an inter-permeation between the internal dynamics of ideology enacted within the family space and the broader discourses prevalent in the external terrain of state level policy. In the context of my research, based on their individual language beliefs, ideologies and management decisions, pro-Galician parents become stakeholders or implementers of language policy in the home domain. Their habitus and their access to different forms of capital and to the community's linguistic culture also play a significant role in this whole process. Their under-the-radar participation in LPP may appear extremely intermittent and ad hoc, but their individual language management and practice, taken together, can have a significant impact in their immediate society's language behaviour.

Funding: This paper benefits from a Short Term Scientific Mission (STSM) that took place in November 2014 under the auspices of the European COST Action 1306 New Speakers in a Multilingual Europe: Opportunities and Challenges.

\section{References}

Althusser, L. 1971. Lenin and Philosophy and Other Essays. New York: Monthly Review Press.

Álvarez, E. 2014. Vázquez sitúa el problema del gallego en que no se emplea al salir de la escuela. 13 December 2014. http://www.lavozdegalicia.es/noticia/galicia/2014/12/13/ vazquez-situa-problema-gallego-emplea-salir-escuela/0003_201412G13P5994.htm (accessed 12 January 2016).

Álvarez-Cáccamo, C. 2011. Contra o capitalismo linguístico: perante a crise da língua na Galiza'. Agália Revista de Estudos na Cultura 104(2). 11-28.

Bal, R. \& I. Rodríguez. 2014. Pais e profesionais organízanse para impulsar o ensino en galego. 06 March 2014. http://www.galiciaconfidencial.com/noticia/17979-pais-profesionais-orga nizanse-impulsar-ensino-galego (accessed 19 June 2016).

Braun, V. \& V. Clarke. 2006. 'Using thematic analysis in psychology.' Qualitative Research in Psychology 3(2). 77-101. doi: 10.1191/1478088706qp0630a (accessed 12 August 2017).

Canagarajah, S. ed. 2005. Reclaiming the local in language policy and practice. Mahwah: Lawrence Erlbaum Associates.

Cassels-Johnson, D. 2013. Language Policy. London: Palgrave Macmillan.

Curdt-Christiansen, X. L. 2009. Visible and invisible language planning: Ideological factors in the family language policy of Chinese immigrant families in Quebec'. Language Policy 8(4). 351-375.

Curdt-Christiansen, X. L. 2013. 潜移默化 - Implicit learning and imperceptible influence: Syncretic literacy of multilingual Chinese children. Journal of Early Childhood Literacy 13(3). 345-367.

Curdt-Christiansen, X. L. 2014. Family language policy: Is learning Chinese at odds with learning English? In X. Curdt-Christiansen \& A. Hancock (eds.), Learning Chinese in Diasporic Communities, 35-55. Amsterdam: John Benjamins. 
Curdt-Christiansen, X. L. 2016. Conflicting language ideologies and contradictory language practices in Singaporean bilingual families. International Journal of Multilingual and Multicultural Development 37(7). 694-709. doi: 10.1080/01434632.2015.1127926 (accessed 12 April 2016).

Del Valle, J. 2000. Monoglossic policies for a heteroglossic culture: misinterpreted multilingualism in modern Galicia. Language and Communication 20. 105-132.

Derrida, J. 1976. Of grammatology. Baltimore: Johns Hopkins University Press.

Flores, N. 2013. Silencing the subaltern: Nation-State/colonial governmentality and bilingual education in the United States. Critical Inquiry in Language Studies 10(4). 263-287.

Fogle, L. W. 2013. Parental ethnotheories and family language policy in transnational adoptive families. Language Policy 12(1). 83-102.

Foucault, M. 1978. The History of Sexuality, an Introduction, Volume I. New York: Randome House, Inc.

Foucault, M. 1980. Power/Knowledge: Selected Interviews and Other Writings, 1972-1977. New York: Pantheon.

Foucault, M. 1991. Governmentality. In G. Burchell, C. Gordon \& P. Miller (eds.), The Foucault effect: studies in governmentality, 87-104. Chicago: The University of Chicago Press.

Foucault, M. 2007. Security, Territory, Population: Lectures at the College de France 1977-78. Basingstoke: Palgrave Macmillan.

Hermida, X. 2014. Feijóo atribuye a las familias la caída del uso del gallego entre los niños. El País. 14 December 2014. http://ccaa.elpais.com/ccaa/2014/12/11/galicia/1418331110_ 158611.html (accessed 12 January 2017).

Instituto Galego de Estatística. 2014. Enquisa de Condicións de Vida das Familias. Coñecemento e Uso do Galego. Ano 2013. Santiago de Compostela: Instituto Galego de Estatística (IGE). www.ige.eu (accessed 18 June 2017).

Kaplan, R. B. \& R. B. Jr. Baldauf. 1997. Language Planning: From Practice to Theory. Clevedon: Multilingual Matters.

King, A. K. 2016. Language policy, multilingual encounters, and transnational families. Journal of Multilingual and Multicultural Development 37(7). 726-733. doi: 10.1080/ 01434632.2015.1127927 (accessed 23 August 2016).

King, K. A., L. Fogle \& A. Logan-Terry. 2008. Family language policy. Language and LinguisticsCompass 2(5). 907-922.

Lanza, E. 2007. Multilingualism and the family. In P. Auer \& L. Wei (eds.) Handbook of Multilingualism and Multilingual Communication, 45-66. Berlin: Mouton de Gruyter.

Lorenzo-Suárez, A. M. 2005. Planificación lingüística de baixa intensidade: o caso galego. Cadernos de Lingua 27. 37-59.

Marková, I., P. Linell, M. Grossen \& A. Salazar-Orvig. 2007. Dialogue in focus groups: exploring socially shared knowledge. London: Equinox.

Martin-Rojo, L. 2017. Language and Power. In O. García, N. Flores \& M. Spotti (eds.) The Oxford Handbook of Language and Society, 77-102. Oxford/New York: Oxford University Press.

McCarty, M. 2015. Ethnography in Language Planning and Policy Research. In F. M. Hult \& D. Cassels-Johnson (eds.) Research Methods in Language Policy and Planning: A Practical Guide, 81-93. West Sussex, UK: Wiley Blackwell.

Monteagudo, H. 2012. Política lingüística en Galicia: Apuntes para un nuevo balance. In G. Kremnitz, P. Cichon \& B. Czernilofsky-Basalka (eds.) Quo vadis, Romania?, 21-39. Wien: Institut für Romanistik, Universität Wein. 
Monteagudo, H., X. Loredo \& M. Vázquez. 2017. Lingua e sociedade en Galicia: a evolución sociolingüística 1992-2013. A Coruña: Real Academia Galega.

Nandi, A. 2016. Language policies on the ground: Parental language management in urban Galician homes. Unpublished doctoral thesis. Edinburgh, United Kingdom: Heriot-Watt University.

Nandi, A. \& A. I. Devasundaram. 2017. Contesting the Conventionalising of Castilian: The Role of Galician Parents as Counter-Elites. In F. Lauchlan \& M. C. Parafita-Couto (eds.) Bilingualism and Minority Languages in Europe: Current trends and developments, 12-33. Newcastle upon Tyne, United Kingdom: Cambridge Scholars Publishing.

O'Rourke, B. \& F. Ramallo. 2015. Neofalantes as an active minority: understanding language practices and motivations for change amongst new speakers of Galician. International Journal for the Sociology of Language 231. 147-165.

Shohamy, E. 2006. Language Policy: Hidden Agendas and New Approaches. London/New York: Routledge.

Silva-Valdivia, B. 2010. Máis competentes en castelán que en galego. Tempos Novos 158. 43-47.

Smith-Christmas, C. 2016. Family Language Policy: Maintaining an Endangered Language in the Home. Basingstoke: Palgrave Macmillan.

Spolsky, B. 2004. Language Policy. Cambridge/New York: Cambridge University Press.

Spolsky, B. 2009. Language management. Cambridge: Cambridge University Press.

Urla, J. 2012. Reclaiming Basque: Language, Nation, and Cultural Activism. Reno, USA: University of Nevada Press. 